\title{
Greek Subjects, Greek-American Artists, and American Abstract Expressionism
}

\author{
By Gail Levin*
}

\begin{abstract}
Many Abstract Expressionists in America found in Greek mythology rich material to express metaphoric meaning that could be communicated through the referential titles that they gave to their art, even when they stayed far away from literal representation. In the work of some Abstract Expressionists, these metaphors have been interpreted as referring to the tragic events of World War II. Yet for the Greek-American artists among and around the Abstract Expressionists, references to Greek myths came naturally through pride in their ancestral culture.
\end{abstract}

Abstract Expressionists in the United States took a vigorous interest in classical Greek myths. They were following the lead of Surrealists in Europe, such as André Masson and Matta, as well as Picasso, who had absorbed Freud and turned to classical mythology. The Surrealists also admired Giorgio de Chirico's painting with his classical references. His allusions to Greek mythology resulted from his birth in 1888 in Volos, Greece, to a Genovese mother and a Sicilian father. Giorgio grew up and studied in Athens before moving to Germany in 1906. From 1936, De Chirico's work attracted attention in New York, where it was often shown, especially that year at the Pierre Matisse Gallery and in the Museum of Modern Art's show, Fantastic Art, Dada, and Surrealism.

American artists not only admired De Chirico's paintings, but felt Masson's influence firsthand since he took refuge in the United States during World War II. By then, Masson had already absorbed mythological themes drawn from ancient Greece and from Freud's writings on the dream and the unconscious. Between 1932 and 1934 alone, Masson painted works reflecting his increasing engagement with Greek myth, including The Silenuses (1932), Bacchanal (1933 and 1934), Daphne and Apollo (1933), Orpheus (1934), and The Horses of Diomedes (1934). Masson did not just take his subject matter from classical mythology, he also paraphrased classical forms, such as that of a running figure of Apollo from a Greek vase. Among the Americans who encountered Masson's work was Jackson Pollock, who became in the 1940s, one of the pioneers of Abstract Expressionism. Pollock certainly knew Masson's work and he probably encountered the French artist in the printmaker Stanley William Hayter's Atelier 17, where both artists worked during the 1940s.

* Distinguished Professor, The City University of New York, USA. 
The notion that classical influence on American art came only from modern European artists has been modified by studies that document how the American modernists sought to define themselves by their own return to the classical past. They understood classicism through the filtering medium of Freud and Nietzsche. Above all Nietzsche's Birth of Tragedy from the Spirit of Music gave a central role to myth and to the artist. ${ }^{1}$ This return to Greco-Roman myth via Freud and Nietzsche can be extrapolated yet further by recalling how widespread the impact of Freud and Nietzsche had already been in the other arts, penetrating and transforming American consciousness since the century's first decades. The Abstract Expressionists were thus enmeshed in a process of cultural realignments that had been under way in America since before the First World War.

In 1914, Walter Lippmann, who had studied with William James at Harvard, inaugurated a long career on the New York intellectual scene by publishing $A$ Preface to Politics, which brought the theories of Nietzsche, Henri Bergson and Freud to bear on American public life. ${ }^{2}$ Sexuality, mythic reverberation and the shock of contemporary intrusion also characterizes the painting Persephone (1939) by Thomas Hart Benton, the teacher of Jackson Pollock at the Art Students League in New York. Benton's painting Persephone arguably became one of the most notorious visual icons of the tumultuous period between the wars. Benton presented his nude Persephone in the puritanical American heartland, creating a commotion by evoking the figure of a local farm girl sunning herself. Benton conceived of a nude Persephone that mingles classical and popular forms, resembling at once the old master Correggio's version of the myth of Antiope visited by Jupiter, as well as the pinup art popular during the era when Benton painted Persephone. He would follow this classical theme eight years later with his painting, Hercules and Achelous (1947).

Benton's image of Persephone contains some details that reinforce the classical reverberation for the informed viewer. Thus, the grain harvest in the background recalls the goddess of grain and fertility, Demeter, the mother of Persephone. The mule-drawn wagon ironically reinterprets the chariot in which Persephone's uncle, Pluto, carried her off. The vines of Dionysus creep into the foreground. The curves of the female form merge with the land, leading interpreters to see a new version of the old metaphor that identifies the fecundity of earth and woman. The corollary, which was not uncommon in American art of the time, was that the agricultural exploitation, which produced the Great Depression's dust bowl, had been a rape. ${ }^{3}$

1. Stephen Polcari, Abstract Expressionism and the Modern Experience (Cambridge: Cambridge University Press, 1993), 54-55.

2. F. J. Hoffman, Freudianism and the Literary Mind (New York: Grove Press, 1959), 54.

3. Henry Adams, Thomas Hart Benton, an American Original (New York: Alfred A. Knopf, 1989), 289. 
The link from Benton to Pollock, whom Benton taught during the 1930s, is certain. During the heyday of this last hurrah of modernism, artists took a vigorous interest in classical myth. Pollock changed the title of a major abstract painting from Moby Dick to Pasiphae (c. 1943) after the curator, James Johnson Sweeney told him the story of the Cretan queen who fell in love with the white bull sent by Poseidon to her husband, King Minos of Crete. Pollock left two sheets of notes on Pasiphae, complete with quotations from Ovid and Dante. ${ }^{4}$

Yet even without a teacher immersed in classical myth such as Benton was, Pollock's contemporaries, painters such as Adolph Gottlieb, Mark Rothko, William Baziotes, Barnett Newman, Lee Krasner, Byron Browne, and Romare Bearden, as well as the sculptor Isamu Noguchi (and Noguchi's occasional collaborator, the choreographer Martha Graham,) all drew upon classical themes, giving mythic titles to works produced in the 1940s.

Noguchi was the son of a Japanese writer and an Irish-American mother, who taught him as a child about classical myth, which he later related to Japanese mythology. Noguchi met Graham through his mother, Leonie Gilmour, who helped with costumes for Graham's dance company. When Noguchi designed sets and costumes in 1946 for Graham's Cave of the Heart, based on the story of Medea, he called it a "dance of transformation as in the Noh drama." Noguchi wrote about his collaboration in 1948 with Igor Stravinsky and George Ballanchine on the ballet Orpheus, for which he designed sets and costumes:

I interpreted Orpheus as the story of the artist blinded by his vision (the mask). Even inanimate objects move to his touch-as do the rocks, at the pluck of his lyre. To find his bride or seek his dream or to fulfill his mission, he is drawn by the spirit of darkness to the netherworld. Here, too, entranced by his art, all obey him; and even Pluto's rock turns to Eurydice in his embrace. ${ }^{5}$

The following year, Noguchi traveled to Europe, where he visited Pompeii, describing the nearby Villa of the Mysteries as a "beautiful integration of painting and architecture;" Paestum, where he saw the Temple of Poseidon and commented on the "sacred relation of man to nature" and Greece, among other places. ${ }^{6}$ He sketched an ancient sculpture of Apollo as the shepherd. Noguchi even titled one of his abstract marble sculptures Kouros (1944-45) after the archaic Greek male figures stiffly carved in marble. He also continued to choose titles that make reference to the classics. In one case, he called a bronze sculpture Cronos (1947) after the Titan son of Uranus and Gaia who was the father of Zeus. In

4. Francis V. O'Connor and Eugene Thaw, Jackson Pollock: A Catalogue Raisonné (New Haven, CT: Yale University Press, 1978) vol. I, 78.

5. Dore Ashton, Noguchi East and West (New York: Alfred A. Knops, 1992), 6.

6. Ibid., 82. 
another case, he named a two-part marble sculpture Euripides (1966). In order to acquire Greek marble for his sculptures, Noguchi often stopped off in Greece en route to America from Japan.

One of the closest students of classical myth was the painter Mark Rothko (1903-1070). His famous radio broadcast of 1943, made together with his longtime friend Adolph Gottlieb, shows how Nietzschean and Freudian thinking led to new interest in myth:

If our titles recall the known myths of antiquity, we have used them again because they are the eternal symbols upon which we must fall back to express basic psychological ideas. They are the symbols of man's primitive fears and motivations, no matter which land or what time, changing only in detail but never in substance, be they Greek, Aztec, Icelandic, or Egyptian. And modern psychology finds them persisting still in our dreams, our vernacular, and our art for all the changes in the outward conditions of life. ${ }^{7}$

In Rothko's case, he may even have taken time out from painting to study myth, in order "to break with what they considered stagnant in the European tradition and with the provincial American past."8

Rothko invoked the ancient religious practice of predicting the future course of events in his canvas, The Omen of the Eagle (1942). In it, he drew upon Greek literature, specifically Agamemnon, the first play of the Orestia by Aeschylus, in which two eagles sweep down on a pregnant hare and devour its unborn young, an omen of the coming war with Troy and the sacrifice of Iphigenia. Here the image of feet gets adapted from chiton-clad figures in Greek vase painting. ${ }^{9}$ Rothko also chose themes from the Sophocles's Oedipus trilogy, including Tiresias (1944), the seer of Thebes, who was blinded, but long-lived and prophetic. This suggests metaphorically Rothko's own vision about the future of art, as he renounced the tradition of representation.

Rothko's colleague, Adolph Gottlieb (1903-1974), produced, in addition to other classical subjects, a series of paintings from 1941 to 1945 on the Oedipus myth. In the Hands of Oedipus (1943) and the Eyes of Oedipus (1945), we can see Gottlieb's concern with vision, recalling that in Sophocles' play. Once Oedipus saw the tragic truth behind and beyond appearance and circumstance, he turned against literal sight and destroyed its organs, gouging out his own eyes. It is tempting to speculate that this myth appealed to Gottlieb for its bearing on his own spiritual and artistic development. As he, a Jew, sought to express his pain at

7. Mark Rothko quoted in Polcari, Abstract Expressionism and the Modern Experience, 118.

8. Adolph Gottlieb's wife, Esther, quoted in Anna Chave, Mark Rothko: Subjects in Abstraction (New Haven, CT: Yale University Press, 1989), 78.

9. Polcari, Abstract Expressionism and the Modern Experience, 123. 
the Holocaust, the human tragedy he had no power to stop, he turned away from representational art towards painting, where one no longer sees a literal object. The state of the world may have seemed beyond representation.

Other members of the Abstract Expressionists' coterie drew upon classical myth: Onyx of Electra (1944) by Eduardo Matta, a Chilean-born Surrealist, who had moved from Paris to New York for a time; Barnett Newman's Song of Orpheus (1944-45); Theodore Stamos, The Sacrifice (1946); William Baziotes's Cyclops (1947) or The Flesh Eaters (1952); and, a bit later, Lee Krasner's Gaea (1966) and Icarus (1964).

In the same period, an African-American artist, Romare Bearden (19111988), showed his more representational pictures with many of the Abstract Expressionists, particularly at the Samuel Kootz Gallery in New York, where he knew Gottlieb, Baziotes, and Hans Hofmann (who immigrated to the United States from Germany). All of these artists used classical references in their work during the 1940s.

In 1947, Bearden, an avid reader, began a series related to Homer's Iliad. Working in oil he produced such paintings as The Walls of Ilium, where, fascinated by the tragedy of the city destroyed, he showed flames shooting out from Troy's stone walls. In 1948, he also produced a series of watercolors inspired by the Iliad, where the walls resemble those in the oil painting. Many of these watercolors focused on two individuals, as in The Parting Cup, where a woman offers a goblet to her departing warrior. Continuing his engagement with classical myth, Bearden produced in 1977 twenty large collage depictions of Homer's Odyssey. For this project, he mixed classical antiquity with the iconography of African American experience. He imagines the treacherous goddess Circe, as a seductive black-skinned figure surrounded by bold colors that suggest a jazz performer.

Most notable among the Greek-American participants are William Baziotes (1912-1963), Theodoros Stamos (1922-1997), Aristodemus Kaldis (1889-1979) and Peter Voulkos (1924-2002). Except for Kaldis who was born in Asia Minor in Turkey and raised in Greece, each of these artists was born of Greek immigrant parents who arrived in the United States before the imposition of strict quotas limiting immigration from Greece, Eastern Europe, and other areas during the 1920s. Most of the Greek immigrants settled in large urban areas like New York, where visual culture was more developed, but Greek-American artists developed all around the United States. Despite pressures to assimilate, Greek identity survived in coffee shops, schools and churches. The artists sometimes referenced Greek myths to underscore their Greek identity and this is revealed in their art.

Aristodemus Kaldis, who arrived in New York in 1917, at the age of eighteen, recalled frequenting colorful and cheap Greek coffee shops with artists in the Abstract Expressionist circle, including Lee Krasner, Arshile Gorky, Byron Browne, and Willem de Kooning. He was known for his art history lectures, but he also painted. At first his work was figurative: his Absorbing Art of 1941 features a Greek icon hanging on the wall. It attracted an important buyer - the 
Philadelphia collector and art educator, Albert Barnes. Later, Kaldis felt the influence of Vasily Kandinsky's work and became an abstract painter. In his works, Panhellenic \# 2 of 1956 and Aegean Church 1976, however, he returned to representation, embracing the Greek landscape.

William Baziotes was born and raised in Pittsburgh, Pennsylvania, to Greek immigrant parents. He came to New York in 1933 to study at the National Academy of Design. He commented:

Today it is possible to paint one canvas with the calmness of an ancient Greek and the next with the anxiety of a Van Gogh. Either of these emotions, and any in between, is valid to me ... I work on many canvasses at once. In the morning I line them up against the wall of my studio. Some speak, some do not. They are my mirrors. They tell me what I am like at that moment. ${ }^{10}$

We can see the embrace of Greek mythology by Baziotes in a painting such as his Cyclops (1947), which refers to Homer's one-eyed monster shepherd, who like to eat human flesh. In the Odyssey, Odysseus escaped death by blinding the Cyclops Polyphemus. Baziotes managed to express in one image both his Greek identity and his post-war anxiety.

Theodore Stamos was born on Manhattan's Lower East Side to Greek immigrant parents. He attended art school in New York and met some avantgarde artists while working in a frame shop. From 1943-1957, he showed at the Betty Parsons Gallery, which also showed Pollock and Barnett Newman. Stamos painted biomorphic abstractions that he named Cyclops (1947) or Sacrifice (1947), suggesting that, like Baziotes, he was making a reference to the end of World War II. His colleague, the artist Barnett Newman, wrote in his introduction to Stamos' 1947 exhibition with Betty Parsons Gallery, "His ideographs capture the moment of totemic affinity with the rock and the mushroom, the crayfish and the seaweed. He re-defines the pastoral experience as one of participation with the inner life of the natural phenomenon." 11 Newman could have been making a reference to the parallel of Greek bucolic poetry.

In 1948 and 1949, Stamos traveled to Europe, visiting parts of Greece. He later developed abstractions such as Infinity Field (1975) inspired by the Greek island, Lefkada, where his father was born and where he began to spend much of his time from 1970 until his death in 1997. In 1996, Stamos donated forty-three of his paintings to the National Gallery of Greece.

Peter Voulkos, another son of Greek immigrant parents, was born in Montana in the American West. He attended art school there. Not until after he

10. William Baziotes, "I Cannot Evolve Any Concrete Theory," Possibilities I, no. 1 (Winter 1947-48): 2.

11. Barnett Newman, Theodoros Stamos (New York: Betty Parsons Gallery brochure). 
served in the military during World War II, did Panagiotis Voulkos, as he was called at birth, shorten his name and settle in California. Passing through New York City, he met some of the Abstract Expressionists, whose work influenced his attitude toward his ceramics. In the summer of 1953, Voulkos taught a ceramics course at Black Mountain College in Asheville, North Carolina, at the same time that the Spanish-born Abstract Expressionist painter, Esteban Vicente, taught there. Voulkos saw his own abstract work as "violating" form, creating energy, since he made ceramic sculpture freer, more spontaneous, and new in form.

Following the Abstract Expressionists, the contemporary artist, Lynda Benglis, was born in 1941 in Louisiana of a Greek-immigrant father and American mother. She has made sculpture and videos. She mimicked and honored Pollock's flinging and dripping methods of painting with sculptures in the 1960s, such as Blatt (1969), commenting on his style with her poured sculpture. In 1971, she made wall-mounted sculptures that looked as if they had been dripped, which she called Totem. For this reason, her work has been included in some international surveys of "Action Painting," which is the name the art critic Harold Rosenberg coined for Abstract Expressionism. ${ }^{12}$ In an interview, Benglis commented, "Like most young artists starting out, my paintings were of the figure and landscape, but they were quite involved with color in a Rothkoesque sense. I was making images through touch and process."13 Not only did she admire Rothko's color, but she became friends with the Abstract Expressionist, Barnett Newman and his wife, Annalee.

Benglis's work is often on view and well represented in the Museum of Modern Art in New York. Her work both looks back to Abstract Expressionism with irony and ahead to newer styles. She makes us appreciate the bold innovation of Abstract Expressionism as well as pointing out the humorous aspects of the movement's drips.

\section{Conclusion}

To summarize, many American Abstract Expressionist artists found in Greek mythology rich material to create metaphoric meaning that could be communicated through the referential titles that they gave to their work, even when they stayed far away from literal representation. For the Greek-American artists among and around the Abstract Expressionists, such references came naturally through pride in their ancestral culture.

This Greek-American pride in their ancestral culture was complicated, however, by catastrophic events in Greece during World War II, particularly the

12. Robert Fleck et al., Action Painting (Basel, Switzerland: Beyeler Foundation, 2008).

13. Lynda Benglis in conversation with Phong Bui, The Brooklyn Rail, December 11, 2009. 
fate of the country's Jews, who had lived in Greece at least since the fourth century before the common era. ${ }^{14}$ After Greece fell to Nazi Germany in World War II, its Jewish population was almost obliterated, suffering immense loss. ${ }^{15}$ The tragedy that transpired in Greece was so extreme as to merit special comment in the present study.

Under the Nazi German occupation, Salonika, where Greece's largest Jewish community lived, saw Jewish homes, academies, synagogues, and the hospital captured and the plunder sent to Germany. On July 11, 1942, the Germans ordered 9,000 Jewish men with Greek citizenship to gather and be registered for forced labor, beating and humiliating them. The Jewish community had to pay a ransom for their release. It did so by selling Salonika's Jewish cemetery to the city administration. The city destroyed the cemetery, breaking up the tombstones, which it later used to build a university on the site. ${ }^{16}$

American newspaper and magazine accounts bore witness to some of what was going on in Europe. On May 1, 1944, the New York Times reported belatedly "that the tragic climax to the 'inhuman persecution by the Nazi occupation in Greece' came in April, 1943, when nearly the entire population of 48,000 Jews from Salonika was herded 'like cattle' into cars which comprised seventeen trains and were carried off to Poland."17 News accounts in other less prominent publications would have preceded this one. ${ }^{18}$

How to respond to such atrocity in one's art, especially for Jewish artists, was complicated. The timing of reference to ancient Greek myth made by Rothko, Gottlieb, and Newman strongly suggests that they alluded to the Holocaust, to the specific tragedy that their fellow Jews were then suffering in contemporary Europe. Many scholars have proposed that they responded to these recent events. Yet, these artists did not want to be branded as "Jewish" artists, because it was such a limiting category. ${ }^{19}$ Still, decades later, Rothko's friend, the sculptor George Segal, reported that Rothko told him, "Studying

14. Martin Goodman, Jews in a Graeco-Roman World (Oxford: Oxford University Press, 2004).

15. Steven B. Bowman, The Agony of Greek Jews, 1940-1945 (Stanford, CA: Stanford University Press, 2009).

16. See website of the United States Memorial Holocaust Museum (as of 5-26-2016): https://goo.gl/fhJDo5.

17. "48,000 Greek Jews are Sent to Poland: Shelter Society Receives Report of German Persecution," New York Times, last modified May 1, 1944, 5.

18. Alex Grohman, "When Did They Know? The American Jewish Press and the Holocaust," Journal of American Jewish History 68, no. 3 (1979).

19. Andrea Pappas, "Invisible Points of Departure: Reading Rothko's Christological Imagery," American Jewish History, 92, no. 4, (2004). 
Jewish history will give you the opportunity to deal with spiritual states."20

During its occupation, the German Army enforced the deportation of Jews all across Greece. Almost all of the people deported were murdered on or shortly after April 11, 1944, when the train carrying them reached Auschwitz-Birkenau. Nearly 13,000 Greek Jews fought in the Greek Army, which held off the Italian Army, but was later overwhelmed by German forces. Eventually nearly 70,000 Greek Jews $-81 \%$ of the entire Jewish population-were murdered. Survivors include those saved by their Christian neighbors who risked their own lives by hiding Jews and those saved by the Greek Orthodox Church, once the defiant Archbishop Damaskinos arranged for false baptismal certificates to be issued to all Jews who requested them. Indeed, this act of Christian mercy took place not long before Mark Rothko, who, before his journey to America, had trained as a child in an Orthodox Jewish religious school in Latvia, painted an abstract watercolor with a Christian reference, Baptismal Scene (1945).

\section{Bibliography}

Adams, Henry. Thomas Hart Benton, an American Original. New York: Alfred A. Knopf, 1989.

Ashton, Dore. Noguchi East and West. New York: Alfred A. Knops, 1992.

Baziotes, William. "I Cannot Evolve Any Concrete Theory." Possibilities I, no. 1 (Winter 1947-48).

Bowman, Steven B. The Agony of Greek Jews, 1940-1945. Stanford, CA: Stanford University Press, 2009.

Chave, Anna. Mark Rothko: Subjects in Abstraction. New Haven, CT: Yale University Press, 1989.

Fleck, Robert, Jason Kaufman, Gottfried Boehm, Pepe Karmel and Ulf Küster. Action Painting. Basel, Switzerland: Beyeler Foundation, 2008.

Goodman, Martin. Jews in a Graeco-Roman World. Oxford: Oxford University Press, 2004.

Grohman, Alex. "When Did They Know? The American Jewish Press and the Holocaust." Journal of American Jewish History 68, no. 3 (1979).

Hoffman, F. J. Freudianism and the Literary Mind. New York: Grove Press, 1959.

Newman, Barnett. Theodoros Stamos. New York: Betty Parsons Gallery brochure.

20. Mark Rothko to George Segal, quoted in George Segal Interview by Mark Rosenthal, September 8, 1997 in Jeffrey Weiss, Mark Rothko (Washington, DC: National Gallery of Art, 1998), 373. 
O’Connor, Francis V., and Eugene Thaw. Jackson Pollock: A Catalogue Raisonné. New Haven, CT: Yale University Press, 1978.

Pappas, Andrea. "Invisible Points of Departure: Reading Rothko's Christological Imagery." American Jewish History 92, no. 4 (2004): 401-437.

Polcari, Stephen. Abstract Expressionism and the Modern Experience. Cambridge: Cambridge University Press, 1993.

Weiss, Jeffrey. Mark Rothko. Washington, DC: National Gallery of Art, 1998.

"48,000 Greek Jews are Sent to Poland: Shelter Society Receives Report of German Persecution." New York Times. Last modified May 1, 1944, 5. 